\title{
Corrections
}

\section{Correction: Mooney, R., Synaptic Basis for Developmental Plasticity in a Birdsong Nucleus}

Some of the findings described in the article "Synaptic Basis for Developmental Plasticity in a Birdsong Nucleus" by Richard Mooney, which appeared on pages 2464-2477 of the July 1, 1992 issue, had been previously described in brief form in Mooney and Konishi (1991). Figure 9 and portions of Figure 10 in Mooney (1992) were reproduced from Mooney and Konishi (1991) with permission of the authors.

The full citations are listed below.

References

Mooney R (1992) Synaptic basis for developmental plasticity in a birdsong nucleus. J Neurosci 12:2464-2477.

Mooney R, Konishi M (1991) Two distinct inputs to an avian song nucleus activate different glutamate receptor subtypes on individual neurons. Proc Natl Acad Sci U S A 88:4075-4079.

DOI: $10.1523 / J N E U R O S C I .5246-12.2013$ 